\title{
Do European Parliament Elections Impact National Party System Fragmentation?
}

\author{
Elias Dinas ${ }^{1}$ and Pedro Riera ${ }^{2}$
}

\begin{abstract}
Why have European large parties lost electoral ground in recent decades? Whereas most explanations draw on theories of dealignment, this article advances a novel, institutional, argument by focusing on the introduction of direct elections to the European Parliament (EP) in 1979. Archetypes of second-order elections, EP elections are characterized by lower vote sharesfor (a) large and (b) incumbent parties. Bridging the second-order electionstheory with theories of political socialization, we posit that voting patternsin EP elections spill over onto national elections, especially among voters not yet socialized into patterns of habitual voting. In so doing, they increasethe national vote shares of small parties. This proposition is examined using an instrumental variables approach. We also derive a set of testable propositions to shed light on the underlying mechanisms of this pattern. Our findings show that EP elections decrease support for big parties at the national arena by inculcating voting habits.
\end{abstract}

\section{Keywords}

European Parliament elections, party system fragmentation, second-orderelections, political socialization, instrumental variables

\footnotetext{
${ }^{1}$ University of Oxford, UK

${ }^{2}$ University Carlos III of Madrid, Spain

\section{Corresponding Author:}

Pedro Riera, Madrid 126, 28903 Getafe, Spain.

Email: priera@clio.uc3m.es
} 
Almost any attempt to portray the trajectory of European party systems over the last half century pays pride of place to what is known as the era of political dealignment (e.g., Dalton, 2002). Traditional, cleavage-driven, partisan lines, it is argued, have gradually eroded, leaving voters increasingly more disengaged from conventional politics in general and detached from mainstream political parties in particular (Crewe \& Denver, 1985). The stylized European voter that emerges from this thesis is more reluctant to embrace parties' ideological stances (Knutsen, 1998) and more volatile in her party preferences (Dalton \& Wattenberg, 2002; Franklin, Mackie, \& Valen, 1992). Perhaps the most unequivocal manifestation of dealignment is the evidence that challenges the key theoretical pillar of the cleavage thesis-namely Lipset and Rokkan's (1967) freezing hypothesis. In contrast to thepicture of party system stability described by these two scholars, Europeanparty systems eventually witnessed the emergence of new parties in recenttimes. Although in most cases these newcomers failed to replace the established parties, they succeeded in entering and often remaining in the club of parliamentary insiders.

But if these facts are clear, their explanation remains a matter of longstanding dispute. The existing literature seems divided into two fronts: On the demand side, many studies point to the role of globalization and other structural developments that have altered the socioeconomic profile of many previous core party supporters (Kriesi et al., 2008). On the supply side, mainstream parties are deemed to have abandoned their constituencies by converging into the position of the median voter (Evans \& Tilley, 2012; Ezrow, de Vries, Steenbergen, \& Edwards, 2011).

Although these explanations enhance our understanding of the changing number of political parties in Europe, they fail to consider the role that institutional developments have played in this process. Drawing on these developments, we offer a complementary explanation for the increasing fragmentation of European party systems. Our starting point is the recognition that the current European electoral setting is not the same today as it wasin 1967. Undoubtedly, the most evident funnel of institutional change has been the process of European unification. In their macrosociological over- view of European party systems, Lipset and Rokkan could not foresee the increasing importance of the European integration project. The initial European Communities have gradually evolved into the currently complex multitier structure of the European Union. This process of integration has been accompanied by the creation and expansion of supranational representative institutions. Perhaps the most notable development in this respect is the introduction of direct elections for the European Parliament (EP) in $1979 .{ }^{1}$

We argue that, at least in part, national party system fragmentation is a function of these European Union (EU)-wide elections. Similar to other institutional designs, EP elections have had unintended consequences, opening the way for the entry and long-term survival of small parties in national 
electorates. In our view, the second-order nature of these elections and the down-stream effects of the act of voting are responsible for this phenomenon. Let us briefly elaborate on these two critical points of our argumentation.

First, one of the leading theories of voting behavior asserts that EP elections are "second-order elections" fought by national parties on the basis of domestic concerns and preferences, and where little is at stake (Reif \& Schmitt, 1980). Precisely because these elections do not determine the formation of any executive power, they invite less strategic thinking, creating incentives for a protest vote, which often goes to small parties. ${ }^{2}$ Second, previous studies have indicated that voting choices can leave a long-term imprinton people's voting trajectories. By converting a preference into a behavioralchoice, the act of voting reinforces prior sentiments about the party or candidate voted for (Bølstad, Dinas, \& Riera, 2013; Markus \& Converse, 1979). This effect seems to be stronger among first-time voters, who are yet to crystallize into particular voting patterns (Meredith, 2009; Mullainathan \& Washington, 2009).

Combining these two lines of reasoning, we derive the following expectations: First, voters should be more likely to vote for a small party in the comingnational election if they have voted in the most recent EP election. Firsttime voters are particularly affected by this pattern. Second and most importantly,this effect might endure over time, leaving its shadow through an enhanced likelihood of opting for small parties in future national elections. Granted on the magnitude of these effects, the continuation of EP elections increases thepool of voters who are likely to opt for a small party in national elections.

To test this hypothesis, we need to identify the effect of EP vote on future national voting choices. The problem, of course, is that people choose whetherto vote and if so what party to opt for in each election. Without a way to randomly assign party choice in EP elections, the selection mechanism cannot be distinguished from the potential-if any-impact of prior vote choices on future voting patterns. We address this problem by using an instrumental variables approach and exploiting the leverage provided by first-time vote experiences. In particular, we use voters' first-time eligibility for an EP election as aninstrument of actual first-time voting behavior. Thus, we compare people whose first eligible election was an EP election with people whose first eligible election was a national election. The interesting question, then, is whethertheir first electoral experiences have implications for national party vote.

Bridging two strands of literature that talk past each other, this study provides a new institutional explanation for the success of small parties in the European electoral setting. The findings indicate that EP elections leave a significant footprint on people's vote records in national elections. In so doing, they help small parties endure and survive in national party competition. Taken as a whole, the results suggest that EP elections are conducive to higherparty system fragmentation over time. This finding calls for 
a shift in scholarlyattention from sociological explanations of dealignment toward institutional factors, pointing in particular to the unintended consequences for national party systems of a specific intervention aimed at establishing a direct chain ofdelegation between the European citizenry and EU institutions. We elaboratemore on the implications of this finding for the standard determinants of national party system fragmentation in the concluding remarks.

\section{EP Elections and the Long-Term Consequences ofthe Act of Voting}

Party systems during the first decades after the Second World War in Western Europe were described as "frozen" (Lipset \& Rokkan, 1967). In such a world, the number of parties was relatively small, and their levels of electoral support remained moderately stable over time. Moreover, the levels of vote shares lost by incumbent parties were kept at rather low rates. None of these patterns hold nowadays. First, a considerable number of countries have registered rising levels of party system fragmentation in recent decades (Best, 2010). Second, predictions of increasing party volatility have been confirmed for a number of countries and years now (Mair, 2002, 2005). And, third, in multiparty systems it is increasingly more frequent to find negative rather than positive effects of government incumbency (e.g., Narud \& Valen, 2008; Rose \& Mackie, 1983; Strøm, 1990). We posit that these developments are in part accounted for by the spillover effects of the direct EP elections introduced in 1979.

Many scholars have argued that EP elections are "second-order elections" fought by national parties on the basis of domestic concerns and preferences where strategic considerations apply to a lesser extent (Hix \& Marsh, 2007, 2011; Reif \& Schmitt, 1980; van der Brug \& van der Eijk, 2007). At the heart of this characterization is the proposition that there is less at stake in such elections than in first-order elections (Franklin \& Hobolt, 2011, p. 68). Reif and Schmitt offer three broad propositions, based on these arguments, to characterize regular differences between aggregate behavior in European and national elections: (a) turnout will be lower in EP elections than in national elections, (b) national government parties will suffer losses in EP elections, (c) large parties will do worse and small parties will do better in EP elections (Marsh, 1998, p. 592).

We focus on propositions (b) and (c). Small parties and opposition parties are likely to benefit in EP elections for various reasons: First, the lower relevance of strategic orientations, often crucial in national elections, renders party size less important in vote choice (van der Eijk \& Franklin, 1996). Second, as an election that takes place amid the national election cycle, EP elections favor antiincumbent vote, which again makes a vote for small parties more likely (Weber, 2011). Third, given that support for the EU resembles a bell-shaped curve (i.e., it is higher among centrist parties and lower among 
extreme parties), Eurosceptic vote is more often than not associated with a vote for an extreme party, which is typically also a relatively small party in national party competition. Hix and Marsh (2007) find that in all EU states from 1979 to 2004 almost $40 \%$ of the volatility in party vote shares in Europeanelections compared with national elections is explained by the transfer of votes from large and governing parties to small and opposition parties.

Although Reif and Schmitt's propositions have been frequently tested with both aggregate- (e.g., Curtice, 1989; Hix \& Marsh, 2007; Marsh, 1998)and individual-level data (Hobolt \& Wittrock, 2011), they have also been subject to criticism. A first line of criticism focuses on whether this process of electoral change across arenas is driven by sincere voting (Reif \& Schmitt, 1980), or whether we should refer to this type of voting change as "instrumental," aiming either at sending a signal to national parties (Oppenhuis, van der Eijk, \& Franklin, 1996) or at balancing representation between national and supranational elections (Carrubba \& Timpone, 2005), similar to subnational and federal elections in the United States and Canada (Erikson, 1988; Erikson \& Filippov, 2001). Other authors have argued that vote choice in European elections cannot be solely attributed to domestic politics, as it alsoreflects preferences over the EU policy agenda (Clark \& Rohrschneider, 2009). For example, the "Green tide" across Europe in the 1989 elections has been explained by voters' demand for having environmental issues tackled at the European level (Curtice, 1989). The Eurosceptic vote can also be linked to this idea. According to Hobolt, Spoon, and Tilley (2009), voters punish governing parties in EP elections because they are generally far more pro- European than the typical voter. Finally, de Vries (2007) casts some additional doubts on the characterization of European elections as mere second-order national elections in those countries where European issues areon the agenda of the national electoral contest.

In light of these alternative theorizations of EU voting, it is important to emphasize that the goal of our study is not to assess the underlying roots of the voting patterns observed in EP elections. Rather, remaining agnostic about the driving forces of vote choices in these elections, we want to highlight the potential long-standing implications stemming from the largely uncontested fact that the vote share of small and opposition parties increases in these elections. ${ }^{3}$ It is evident that previous theoretical accounts see no spillover effect from one arena to the other, which is the building block of our argument. The underlying microlevel mechanism driving such spillover effects is rooted in socialization theories of habit formation and voter learning. It is to these theories that we now turn.

Drawing on Converse's work on political learning (Converse, 1969; Markus \& Converse, 1979), various studies have found that elections are consequential in building habitual support for political parties (Dinas, 2014; Gerber, Green, \& Shachar, 2003; Green \& Shachar, 2000; Meredith, 2009; Mullainathan \& Washington, 2009; Shachar, 2003). The mechanism driving these results seems to lie in psychological processes of cognitive dissonance 
(Festinger, 1957) and identity formation (Turner, 1982). Cognitive dissonance theory postulates that behavior helps individuals justify and rationalize prior attitudes (Festinger \& Carlsmith, 1959). Previous experiments have shown that after having chosen among a series of objects, individuals tend to exacerbate their preference over the selected object (Brehm, 1956). The logicis analogous when choosing among different parties in an election (Beasley \& Joslyn, 2001). The manifestation of a preference into a behavioral choice strengthens the perceived link between the party and the individual. In so doing, it helps people forge political identities by classifying themselves into coarse categories (Bølstad \& Dinas, 2016; Mullainathan, Schwartzstein, \& Shleifer, 2008). Individuals can think of themselves as voters of a specific party or group of parties, defined by their ideology, size, or some other characteristic. Group membership is accompanied by stereotyping; that is, perceptions of how a typical member of the group should behave (Turner, 1982), and voting for the party that classifies into this category forms part of this description (Lupu, 2013). This is how the process of self-categorization fosters continuity in voting patterns over the life trajectory.

Similar to other identities, political identities and self-classifications are formed and crystallized primarily during the period of early adulthood (Plutzer, 2002). It is during these "impressionable years" (e.g., Delli Carpini, 1989; Sears, 1983) that young adults are more responsive to changes in their political environment (Dinas, 2013; Franklin, 2004). These responses tend to leave a long-term imprint on their attitudinal profile (Ghitza \& Gelman, 2013; Stoker \& Jennings, 2008). In contrast, for older people it seems that theprior stock of political information is already too heavy to allow new shocks generate significant changes in people's attitudinal and behavioral outlooks (Schuman \& Corning, 2012). Party choice seems to adhere to this pattern.

Early vote decisions are shown to influence the future partisan outlooks of young voters (Dinas, 2014; Meredith, 2009; Shachar, 2003). Their effects do not seem to necessitate long repetitions of past voting behaviour. Even a small number of consecutive elections is sufficient to generate inertia in voting habits (McPhee and Ferguson 1962; Meredith 2008).

Let us now bring these insights into the context of EP elections. Seen as second-order elections, EP elections are more likely than national elections to encourage a vote for small parties. Voting a small party in one's first election might, in turn, reinforce one's self-identification as a supporter of this party in particular or a specific type of parties to which the chosen party belongs (inour case, small parties). Lack of prior electoral experience makes it easier that such a vote brings young voters into grips with the idea of supporting a small party in general. Having voted for a small party in an EP election, non-established voters are thus more likely to do the same in the coming nationalelections. In contrast, young individuals who have not voted for the first timefor a small party in an EP election are more susceptible to the type of motivations that make large parties increase their support in national elections and are thus more 
likely to vote for the latter at the national level. If electoral choices have spillover effects, these initial electoral stimuli will diffuse across arenas (from EP to national elections) and over time (from the first tofuture elections). This reasoning leads to the first main hypothesis of this study:

Hypothesis 1 (H1): Voting for the first time in an EP election will increasethe likelihood of voting small parties in future national elections.

H1 is based on a two-stage logic: The first stage assumes that voting in EP elections increases the chances of having voted a small party in these elections. The second stage postulates that this voting pattern translates into thenational arena. Both stages represent probabilistic statements, which can beconditioned by several factors. By considering some of these factors, wederive and test a set of complementary hypotheses, which serve to shed lighton each of these stages separately. In particular, the first two additionalhypotheses identify conditions that render the first stage stronger, whereasthe last two look at factors that facilitate the second stage. In all four hypotheses, we expect to see an overall increase in the magnitude of the main effects.First, EP elections do not just provide an opportunity to opt for small par- ties but often tend to favor a vote against the government. Even if the degreeof antiincumbent vote in EP elections might vary between countries andacross elections, it usually affects all parties in office, both minor and majorcoalition partners (Hix \& Marsh, 2007). Thus, we expect voting for the first time in an EP election to help small parties even more when they are not in the government. Although small parties are in general less likely to participate in cabinets, we also find some of them in multiparty cabinets. This logicimplies that the first stage becomes stronger for small parties which were notincumbent when the first election takes place:

Hypothesis 2A (H2A): Voting for the first time in an EP election will increase the likelihood of voting small parties in future national elections, especially when they were not in government at the time of the EP election.

A second factor that qualifies the magnitude of EP electoral effects is the particular location of these elections within the national electoral cycle. Voting patterns between the two types of elections differ more when there is a temporal distance between them. For example, big parties are expected to lose more votes when the EP elections take place at the middle or toward the end of the national cycle than when they take place at the beginning of the national cycle, when honeymoon effects are still vivid (Hix \& Marsh, 2011). Previous research has established a monotone relationship between secondorder effects and the electoral cycle because EP elections can act as marker setting when they take place close to the next national elections (Oppenhuis et al., 1996). According to this idea, voters would be more likely to engage in 
antiincumbent voting in elections with significant temporal distance from the previous first-order election because their discontent would be taken more into account by the parties in government. ${ }^{4}$ Similarly, we could argue that EP elections should be more likely to translate into a vote for a small party when they take place closer to the end of the national electoral cycle, which again would imply a stronger first stage in our argumentation:

Hypothesis 2B (H2B): Voting for the first time in an EP election will increase the likelihood of voting small parties in future national elections, especially when the EP election took place later in the national electoral cycle.

We now turn to the conditions that might qualify the transmission rate of EP vote choices onto the national electoral arena; that is, the second stage ofour argument. The first condition draws on the expectation that individuals' selfclassifications can relate to a specific party or to a type of parties. Thus, those who opted for a small party in their first election become more likely tovote for a small party in future elections either because they want to vote forthe same party or because they want to vote for a small party, even if it is notthe same party as the party they voted for in their first election. We are not in a position to disentangle the two mechanisms because we lack information about individuals' first vote. Yet, both mechanisms are more likely to operateif a party that is small in the current national election was also small in the firstEP election. With regard to the first mechanism, having a party that was small in both elections increases the possibility that voters are actually voting for thesame party in both elections. With regard to the second mechanism, a party that was small in both elections reduces uncertainty about whether it can be generally classified as a small party. According to both mechanisms, being small in both elections strengthens the second stage of our argument (facilitating the transferability of an EP vote into national elections). Consequently, weexpect that a first EP vote is more likely to lead to a vote for small parties infuture national elections if the current size status of parties goes back to the time of the socializing election:

Hypothesis 2C (H2C): Voting for the first time in an EP election will increase the likelihood of voting small parties in future national elections, especially when they were already small at the time of the EP election.

Our last hypothesis draws on the fundamental difference between EP and national elections. As national elections are considered more important thanEP elections, strategic considerations are more likely to apply. A key aspect of such considerations is avoiding a wasted vote, which depends largely on thelevel of permissiveness of the electoral system (Gallagher, 1991). At least since the seminal contribution of Duverger (1954/1964), electoral success of small parties has been understood as a matter of inclusiveness of the electoral 
institutions: Minor parties are expected to perform particularly well in elections conducted according to rules that impose low barriers to their entry into Parliament. In contrast, the emergence and survival of small parties are generally prevented when the electoral system tends to overrepresent large partiesin the Parliament (Cox, 1997). The existence of these institutional differenceshas obvious implications for our argument. The patterns guiding voting behavior in EP elections are more difficult to be reproduced when the national electoral system is restrictive. Although a first EP vote is more likely to produce avote for a small party, friendly institutional settings for small parties are expected to reinforce these preferences, making EP-driven habits easier to be built. Therefore, the likelihood of voting for a small party in a future nationalelection if you have voted for the first time in an EP election should increaseas the permissiveness of the national electoral rules also increases:

Hypothesis 2D (H2D): Voting for the first time in an EP election will increase the likelihood of voting small parties in future national elections, especially when the national electoral system is particularly permissive.

To sum up, previous evidence on the spillover effects of EP electionson national party competition is only scarce. An important exception is Franklin and Hobolt (2011), who compared the turnout rates of those who came of age before an EP election against those who came of age beforea national election, and found that the former are less likely to vote infuture national elections than the latter. Although this evidence points tothe unintended consequences of the introduction of direct EP elections for national turnout rates, it does not address whether there are differences among those who actually vote. We argue that there are such differences, and that these differences might have played a significant role in party competition and party system change over the last few decades. The next section discusses the data and the "Empirical Strategy" used to test our argument.

\section{Empirical Strategy}

To empirically examine our hypotheses, we need to construct two groups to be compared with respect to their overall voting choice trajectories: The treatment group consists of those individuals who first voted in an EP election, whereas the control group consists of those individuals voting for the first time in a national election. We expect a difference in the future voting profiles of the two groups because of their divergent voting choices in their first elections: The treatment group is expected to vote a small party at higher levels than the control group. Thus, the treatment indicator is thetype of first election one takes part in, whereas the mechanism expected to drive the treatment effect is the actual party choice stemming from each election.

The problem with comparing groups on the basis of their actual party 
choice is that voters are free to decide whether to vote and if so which party to opt for. Therefore, we cannot know whether resulting differencesin future voting patterns between the two groups are due to their unobservable taste for voting for a particular party, or whether they are due to their vote choice in their first election. To address this problem, we usevoter eligibility as an instrument of actual voting behavior. In particular,we compare people whose first eligible election was an EP election with individuals whose first eligible election was a national election. We assume that those who came of age before an EP election actually votedand thus took the treatment. Conversely, we assume that those whose first eligible election was a national election did vote in that election and arethus in the control group. We also assume that the former on averageopted more for small parties than the latter. We remain agnostic about whether each individual actually behaved according to our expectations, given her eligibility status. Failing to comply with these expectations makes these individuals immune to our theoretical predictions. Thus, including them into the analysis makes the design more conservative, and finding treatment effects becomes more difficult. ${ }^{5}$

Eligibility is, of course, determined by one's age, and age, in turn, predicts both turnout and vote choices. However, the relationship between age and EP eligibility is nonmonotone. This means that those who came of age before an EP election can on average be approximately as old as those who came of age before a national election. Take the example of Francesca, Italian and born in December 1984. Francesca turns 18 in 2002 and is, thus, ineligible to vote in the 2001 general election. The next general election is in 2006. Before then, however, there is an EP election in 2004 when Francesca is 20 years old and thus eligible to vote. Essentially, we try to see what would be the difference in the probability that Francesca would vote for a small party in the 2013 Italian general election under the counterfactual scenario that she would havebeen first eligible to vote in a national election. To construct this comparisongroup, we can use Italian voters who were born either in December 1986 or in December 1982. On average, they would be of the same age as Francesca.They would differ, however, in that their first election would be a national election. The interesting question, then, is whether these first electoral experiences have left an imprint on their vote choices in subsequent national elections.

To perform our analyses, we need data that cover as many European coun tries as possible and for as much time as possible. For this reason, we use the European Election Studies (EES) surveys from 1989 until 2009 (van Egmond, van der Brug, Hobolt, Franklin, \& Sapir, 2011). EES surveys were fielded in all member states of the EU during the 4 weeks immediately following each EP election. National samples are independently drawn and have approximately 1,000 respondents in each of the EU member states. ${ }^{6} \mathrm{We}$ thus start with 12 countries in 1989 to go up to 27 countries in $2009 .{ }^{7}$

The main shortcoming of the data is the lack of information about the 
exact birthdate of the respondents. ${ }^{8}$ This fact prevents us from using in our analyses those individuals who turn 18 in a year in which either a national election or an EP election takes place because we cannot know whether they do so before the election date or not. In total, 9,224 respondents were excluded for this reason. ${ }^{9}$

As the EP elections started only in 1979, older cohorts who had already come of age when the last national election before the first EP election in each country took place would be all assigned to the control group, thus making this group on average much older than the treatment group. It would, hence, be difficult to disentangle whether any difference between the two groups is due to EP elections or due to their age difference. To eliminate thispossible source of bias, we include only a subset of our survey respondents. In particular, our oldest group of considered voters includes those individualswho were eligible to vote for the first time in the first EP election that takes place in each country.

Figure 1 shows the relative age distributions of the two groups. The zigzagged pattern observed is what would be expected if some year-of-birth cohorts have an EP first election and their adjacent cohorts (either to the left orto the right) are first eligible to vote in a national election. The two vertical lines denote the average age among EP and national eligible voters. There is a slight gap ( 2.5 years), which is mainly due to the fact that for every country-year observation the youngest cohort of voters is EP-eligible because it is formed by those people that came of age before the last EP election. As a way to account for this gap, all our analyses include up to a fourth polynomial of age. The results are robust to the inclusion or exclusion of age as a control variable. ${ }^{10}$

[Figure 1 about here] 
Table 1. Balance Statistics on a Series of Demographics.

\begin{tabular}{|c|c|c|}
\hline & Beta for EligibleEP $(S D)$ & $p$ value \\
\hline Male & $-.007(0.013)$ & .584 \\
\hline Education $=$ up to 14 years & $.004(0.005)$ & .429 \\
\hline Education $=15$ years & $.000(0.007)$ & .939 \\
\hline Education $=16$ years & $-.028(0.030)$ & .355 \\
\hline Education $=17$ years & $.013(0.013)$ & .299 \\
\hline Education $=18$ years & $.020(0.012)$ & .113 \\
\hline Education $>18$ years & $-.028(0.030)$ & .355 \\
\hline Social class $=$ working class & $.053(0.013)^{* * *}$ & .001 \\
\hline Social class $=$ low middle class & $-.004(0.007)$ & .557 \\
\hline Social class $=$ middle class & $-.028(0.007)^{* * *}$ & .001 \\
\hline Social class $=$ upper mid. class & $-.016(0.006) * *$ & .021 \\
\hline Social class $=$ upper class & $-.007(0.003) * *$ & .048 \\
\hline Social class $=$ other & $-.000(0.001)$ & .703 \\
\hline Social class $=$ no classification & $-.000(0.003)$ & .863 \\
\hline Social class = Don’t Knows & $.005(0.005)$ & .274 \\
\hline Social class $=$ not available & $.001(0.002)$ & .659 \\
\hline Social class $=$ missing & $-.002(0.002)$ & .336 \\
\hline
\end{tabular}

The first column represents a set of binary indicators, each used as a dependent variable, regressed on the set of covariates that are included in all models: age (with all four polynomials), country- and EP-term fixed effects and the treatment indicator (EligibleEP). The second column shows the OLS coefficient attached to EligibleEP together with its accompanying standard error(clustered at the country level). The third column presents the corresponding $p$ value for this variable. $\mathrm{EP}=$ European Parliament; OLS = ordinary least squares; $\mathrm{SD}=\mathrm{Standard}$ Deviation.

**Significant at .05 . ***Significant at .01 (two-tailed tests).

Table 1 presents information about other socioeconomic covariates: gender, education, and class. ${ }^{11}$ In general, we find high degree of similarity between the two groups. Yet, some imbalances emerge, especially with respectto class categories. EP eligibles appear more likely to locate themselves intolower socioeconomic class categories. To assess the extent to which these imbalances confound our estimates, we present our results both with and with-out these controls, and they remain robust. The existence of balance with regard to covariates and the robustness of results to the inclusion of them in our specifications lead us to conclude that no other variable (e.g., the existence of popularity mechanisms over the electoral cycle) could affect differently thetreatment and the control groups and drive, hence, our results.

Turning into estimation issues, given that we do not have information about people's actual vote choices in their first eligible elections, we use only the reduced form equation, just comparing the two groups on the basis of their eligibility status. We can thus only recover the intent-to-treat effect, as 
given by $\delta$, the coefficient attached to the eligibility indicator ${ }^{12}$ :

SmallParty EligibleEP $\mathrm{u}$ ist $\mathrm{s}=+\alpha \lambda++\mathrm{t}$ ist + is $\gamma \delta,(1)$

where SmallParty is a dummy that switches on for a vote for small parties forindividual $i$ of country $s$ in election $t$ (i.e., it takes value 0 if the respondent votes for a large party). EligibleEP is also a binary indicator that denotes an EP first eligible voter. The notation also indicates that apart from the inclusion of country- and EP-term fixed effects, ${ }^{13}$ the standard errors are clusteredat the country level. This equation tests H1. To test $\mathrm{H} 2 \mathrm{~A}$ and $\mathrm{H} 2 \mathrm{C}$, we use only a subset of SmallParty; that is, those small parties that were not in government and were not big in the socializing EP election either, respectively. To test H2B and H2D, we interact eligibility with Cycle (i.e., the elapsed proportion of national electoral cycle) and national Average District Magnitude (DM), respectively. ${ }^{14}$ All hypotheses are tested using linear prob-ability models. ${ }^{15}$

Moving to measurement issues, we obtain information on respondents' national vote (i.e., our dependent variable) from the question included in eachEES survey on the party they intend to vote in the next national election. We take these responses, go back to electoral results and accordingly code each of the parties mentioned by the respondent as big or small. To do so, we employ two different strategies: First, we consider a party to be small if it is not one of the two top parties in the last national election. Second, we con- sider a party to be small if it gets less than $10 \%$ of the total votes in the last national election. Each of these two definitions is applied to the moment in which the EES survey is conducted. ${ }^{16}$

\section{Results}

Table 2 presents the first set of results looking at the effect of being eligible to vote for the first time in an EP election on the probability of voting a smallparty in the next national election. In the first two columns of the table, smallparties are considered to be those that are not one of the two top parties in thelast national election (Models 1a and 1b). The last two columns use a different dependent variable, namely a dummy that denotes those parties with lessthan $10 \%$ of the total vote in the last national election (Models $2 \mathrm{a}$ and $2 \mathrm{~b}$ ). Inall cases, those eligible to vote for the first time in an EP election are between 3\% and 4\% more likely to vote for a small party in the next national election (H1). The size of the coefficients is substantively unchanged when different measurements of the dependent variable are used. The results remain robust to the inclusion of covariates (Models $1 \mathrm{~b}$ and $2 \mathrm{~b}$ ). This similarity in the findings enhances our confidence that what we show here is not simply an artifact 
Table 2. Voting for a Small Party in the Next National Election.

\begin{tabular}{lcccc}
\hline & Model 1a & Model 1b & Model 2a & Model 2b \\
\hline Eligible EP & $0.033^{* *}$ & $0.036^{* * *}$ & $0.031^{*}$ & $0.033^{*}$ \\
Election & $(0.013)$ & $(0.012)$ & $(0.017)$ & $(0.017)$ \\
Age polynomials & $\mathrm{Y}$ & $\mathrm{Y}$ & $\mathrm{Y}$ & $\mathrm{Y}$ \\
Country-fixed effects & $\mathrm{Y}$ & $\mathrm{Y}$ & $\mathrm{Y}$ & $\mathrm{Y}$ \\
Period-fixed effects & $\mathrm{Y}$ & $\mathrm{Y}$ & $\mathrm{Y}$ & $\mathrm{Y}$ \\
Covariates & $\mathrm{N}$ & $\mathrm{Y}$ & $\mathrm{N}$ & $\mathrm{Y}$ \\
Observations & 15,118 & 15,118 & 15,118 & 15,118 \\
$R^{2}$ & .094 & .101 & .052 & .061 \\
\hline
\end{tabular}

In Model 1, a party is considered to be small if it is not one of the two top parties in the last national election. In Model 2, a party is considered to be small if it gets less than $10 \%$ of the total votes in the last national election. Models (a) only include country- and EP-term fixed effects. Models (b) also include the following controls, all in fully factorized fashion (using missing values as the reference category): sex, social class, and education (age-finished education). Entries are linear probability coefficients with robust standard errors clustered at the country level in parentheses. EP = European Parliament.

*Significant at .10. ${ }^{*}$ Significant at $.05 . * * *$ Significant at .01 (two-tailed tests).

of measurement error. The impact of a first-time EP vote does not depend on either the exact operationalization of the dependent variable or the addition of sociodemographic variables.

We now turn to the conditioning effects. Do we observe the same pattern for parties that were not in government when the socializing election took place? The evidence that is provided in Table 3 is moderately affirmative. Coming of age before an EP election increases even further the likelihood of voting for a small party if this party was not incumbent at the time of the socializing election. However, the extent to which it does so depends on the exact operationalization of small party. Parties that were not in office when the first EP election took place and were not one of the two top are not more likely to be voted among the individuals of the treatment group (Models 1a and $1 \mathrm{~b}$ ). Although the estimates point to the right direction and the size effects are similar to those reported in Table 2, no statistically significant pattern emerges. This would mean that the results in Table 2 are not strengthened by the fact that most small parties are not in the government. In contrast, our instrument is a very good predictor of respondents' intended voting behavior in future national elections when we define small parties as those that obtain less than $10 \%$ of the vote in the last national election (Models $2 \mathrm{a}$ and $2 \mathrm{~b}$ ). In such circumstances, voters eligible for the first time for an EP election are about $4.5 \%$ more likely to vote in national elections for a small party that was 
Table 3. Voting for a Small Party in the Next National Election (Interaction With Incumbency Status in the Socializing Election).

\begin{tabular}{lcccc}
\hline & Model 1a & Model 1b & Model 2a & Model 2b \\
\hline Eligible EP & 0.028 & 0.030 & $0.034^{*}$ & $0.035^{*}$ \\
Election & $(0.017)$ & $(0.017)$ & $(0.018)$ & $(0.017)$ \\
Age polynomials & $\mathrm{Y}$ & $\mathrm{Y}$ & $\mathrm{Y}$ & $\mathrm{Y}$ \\
Country-fixed effects & $\mathrm{Y}$ & $\mathrm{Y}$ & $\mathrm{Y}$ & $\mathrm{Y}$ \\
Period-fixed effects & $\mathrm{Y}$ & $\mathrm{Y}$ & $\mathrm{Y}$ & $\mathrm{Y}$ \\
Covariates & $\mathrm{N}$ & $\mathrm{Y}$ & $\mathrm{N}$ & $\mathrm{Y}$ \\
Observations & 15,118 & 15,118 & 15,118 & 15,118 \\
$R^{2}$ & .051 & .060 & .042 & .056 \\
\hline
\end{tabular}

In Model 1, a party is considered to be small nonincumbent if it is not one of the two top partiesin the last national election, and it was not in government at the time of the socializing election. InModel 2, a party is considered to be small nonincumbent if it gets less than $10 \%$ of the total votesin the last national election, and it was not in government at the time of the socializing election. Models (a) only include country- and EP-term fixed effects. Models (b) also include the following controls, all in fully factorized fashion (using missing values as the reference category): sex, social class, and education (age-finished education). Entries are linear probability coefficients with robust standard errors clustered at the country level in parentheses. EP = European Parliament.

*Significant at .10. **Significant at $.05 . * * *$ Significant at .01 (two-tailed tests).

not in government when that first EP election took place. Similarly to H1, none of these conclusions are affected by the inclusion of covariates.

As the next step in the analysis, we look at H2B. Drawing on the previous empirical evidence (Hix \& Marsh, 2011), we expect that the probability of voting a small party in an EP election increases monotonically asthe temporal distance between the socializing EP election and the previous national election also increases. ${ }^{17}$ Consequently, EP eligibility should increase even more future votes for small parties when the EP election takes place later along the electoral cycle. Figure 2 illustrates the marginal effect of EP eligibility conditional on the date of one's first election. ${ }^{18}$ As predicted by $\mathrm{H} 2 \mathrm{~B}$, the positive effect of our treatment on the likelihood of voting a small party increases as the national electoral cycle goes by. Tardy elections appear to exacerbate the effect of EP eligibility on future small-party vote in national elections. ${ }^{19}$ As each panel of thefigure illustrates, the results are robust to different operationalizations ofthe dependent variable.

[Figure 2 about here]

The analyses used to test the two previous hypotheses examine variables that affect the first stage of our argumentation. In other words, we looked at factors that increased the likelihood of voting for a small partyin the first place. We now turn to features that qualify the second stage; that is, the transmission rate of EP vote choices onto the national electoral arena. For example, models in Table 4 account for the interactiveeffect of the size status of the party now and in the past, and perform 
Table 4. Voting for a Small Party in the Next National Election (Interaction With Small Status in the Socializing Election).

\begin{tabular}{lcccc}
\hline & Model 1a & Model 1b & Model 2a & Model 2b \\
\hline Eligible EP & $0.046^{* * *}$ & $0.048^{* * *}$ & $0.032^{*}$ & $0.034^{*}$ \\
Election & $(0.014)$ & $(0.013)$ & $(0.017)$ & $(0.017)$ \\
Age polynomials & $\mathrm{Y}$ & $\mathrm{Y}$ & $\mathrm{Y}$ & $\mathrm{Y}$ \\
Country-fixed effects & $\mathrm{Y}$ & $\mathrm{Y}$ & $\mathrm{Y}$ & $\mathrm{Y}$ \\
Period-fixed effects & $\mathrm{Y}$ & $\mathrm{Y}$ & $\mathrm{Y}$ & $\mathrm{Y}$ \\
Covariates & $\mathrm{N}$ & $\mathrm{Y}$ & $\mathrm{N}$ & $\mathrm{Y}$ \\
Observations & 15,118 & 15,118 & 15,118 & 15,118 \\
$R^{2}$ & .073 & .080 & .053 & .060 \\
\hline
\end{tabular}

In Model 1, a party is considered to be small if it is not one of the two top parties in the last nationalelection, and it was not in the socializing election. In Model 2, a party is considered to be small ifit gets less than $10 \%$ of the total votes in the last national election, and it got so in the socializing election. Models (a) only include countryand EP-term fixed effects. Models (b) also include the following controls, all in fully factorized fashion (using missing values as the reference category): sex,social class, and education (age-finished education). Entries are linear probability coefficients with robust standard errors clustered at the country level in parentheses. EP = European Parliament.

*Significant at .10. **Significant at .05. ***Significant at .01 (two-tailed tests).

according to expectations. In all models, respondents who come of age before an EP election are more likely to vote for a small party that wasalso small in the socializing election. Both operationalizations of the dependent variable point to the same pattern. However, it is the combination of not being either first or second in any of the two elections under consideration that seems to be particularly susceptible to the long-termeffects of EP elections.

Finally, we examine H2D. To test whether the impact of first-time eligibility for EP elections on subsequent party choice depends on the permissive- ness of the national electoral system, we interact EP eligibility with average district magnitude in national elections. The complete results of this exercise are presented in the online appendix. Figure 3 graphically illustrates the marginal effect of first-time EP eligibility on voting for a small party across the observed range of average district magnitude at the national level. The figureshows that the effect of voting for the first time in an EP election is strongly conditioned by the permissiveness of the domestic electoral rules. High levels of proportionality exacerbate the direct effect of first-time eligibility in anEP election on the subsequent likelihood of voting a small party. As shown inthe figure, the results are clearly robust to different operationalizations of thedependent variable. It seems safe to conclude that permissive electoral rules at the national level augment the long-term effects of EP eligibility on nationalelectoral trajectories. ${ }^{20}$

[Figure 3 about here] 


\section{Robustness}

Three sets of robustness checks are conducted: The first is a falsification test, which examines whether it is the EP election rather than some unobservable factor that drives the differences between EP and national eligibles. The second intends to assess the robustness of the results to different operationalizations of small parties. The third looks at the mechanism explaining this effect.In particular, it tests whether EP elections drive smallparty support not because of their second-order nature but rather due to the higher relevance of the EU at the national level for the EP eligibles. We present the key findingsfrom each of these tests in turn.

To examine whether the effects attributed here to the EP elections could have been driven by other unobservable factors, we perform a placebo test. We take the countries that were not member states when the first EP election took place in 1979 and create an "artificial" EP election for them. Consider the example of Austria, which becomes a member state in 1995 and celebrates its first EP election in 1996. Although the first four EP elections (i.e., 1979, 1984, 1989, and 1994) did not take place in Austria, we will assume that they did so for the placebo test. If the registered differences so far relatedto some other confounder, we would have to observe similar findings for theplacebo test. We use both operationalizations of small parties, as we also didin the previous analyses. Thus, results replicate Table 2, using the placebo indicator instead of the actual treatment indicator. Table 5 presents the resultsand allows us to rule out this hypothesis. The coefficients of our treatment variable are essentially 0 in all the models. Hence, becoming eligible to votefor the first time before an EP election in a country that is not a member stateyet does not increase the likelihood of voting for a small party in the future.

The second set of tests relates to the coding of small parties. We use two alternative measures, both shrinking further the set of small parties. In particular, we code as small all parties: (a) with up to the fourth highest vote share in the last national election, or (b) with up to $5 \%$ of the total vote in the last national election. We use these measures to replicate the analysis shown in Table 2 and Figures 2 and 3. The results, shown in the online appendix, largely confirm those presented here. Irrespective of how small party is coded, EP eligibles are more likely to vote for them than national eligibles, and this difference increases when (a) the EP election is situated far from the national election and (b) the national electoral system is permissive.

The third set of tests explores the validity of an alternative mechanism that could be driving our results. If small parties are also those parties with more popular views toward the EU among the electorate and if EP eligibles are more likely to think about the EU when voting nationally, it might be 
Table 5. Voting for a Small Party in the Next National Election (Placebo Test).

\begin{tabular}{lcccc}
\hline & Model 1a & Model 1b & Model 2a & Model 2b \\
\hline Eligible EP & -0.002 & -0.003 & -0.001 & -0.003 \\
Election & $(0.044)$ & $(0.041)$ & $(0.045)$ & $(0.042)$ \\
Age polynomials & $\mathrm{Y}$ & $\mathrm{Y}$ & $\mathrm{Y}$ & $\mathrm{Y}$ \\
Country-fixed effects & $\mathrm{Y}$ & $\mathrm{Y}$ & $\mathrm{Y}$ & $\mathrm{Y}$ \\
Period-fixed effects & $\mathrm{Y}$ & $\mathrm{Y}$ & $\mathrm{Y}$ & $\mathrm{Y}$ \\
Covariates & $\mathrm{N}$ & $\mathrm{Y}$ & $\mathrm{N}$ & $\mathrm{Y}$ \\
Observations & 3,270 & 3,270 & 3,270 & 3,270 \\
$R^{2}$ & .129 & .144 & .077 & .099 \\
\hline
\end{tabular}

The table presents a placebo test by adding "artificial" EP elections to those countries that were not member states when the first EP election took place in 1979. In Model 1, a party is consideredto be small if it is not one of the two top parties in the last national election. In Model 2, a partyis considered to be small if it gets less than $10 \%$ of the total votes in the last national election.Models (a) only include country- and EP-term fixed effects. Models (b) also include the following controls, all in fully factorized fashion (using missing values as the reference category): sex, social class, and education (age-finished education). Entries are linear probability coefficients with robust standard errors clustered at the country level in parentheses. EP = European Parliament.

*Significant at .10. **Significant at $.05 . * * *$ Significant at .01 (two-tailed tests).

that EP elections lead to party system fragmentation not because of their second-order characteristics but rather because they operate as channels through which considerations about the EU become more salient among voters. Within this framework, we could conceivably think of a spillover from the EU to the domestic arena even if integration is only loosely connected to the left-right dimension (Dalton, Farrell, \& McAllister, 2011; Rohrschneider \& Whitefield, 2012). In either way, this line of reasoning would only qualify the habituation mechanism driving our theory rather than our testable predictions.

To see whether EP elections lead to small-party vote by converting the EU into a more important issue among EP eligibles, we compare the two groupsEP and national eligibles - with respect to their attitudes toward the EU. We employ a variety of tests, capturing differences both in the direction and in the extremity of preferences. We provide a detailed description of these analyses together with the results in the online appendix. The findings suggest that the two groups do not differ in their attitudes toward the EU. Taken as a whole, the results provide little support to the argument that the EP elections generate fragmentation by making the EU more salient among EP eligibles. Rather, it seems that higher levels of small-party vote among EP eligibles are more likely to be the outcome of a habituation process based on early voting experiences.

\section{Conclusion}

It is hardly surprising that, when the elections for the EP were introduced in 
1979, there was no discussion about how they might affect party competition within the member states. The fundamental aim of this reform was to enhance political representation and add legitimacy to what seemed an everincreasing elite-driven process of European integration. The fact that until recently the EP did not have significant competencies has been reflected in the second-order character of these elections. This did not seem to be a problem until the Eurosceptic political actors that gradually emerged in many memberstates found channel into national politics. The findings from this study suggest that one of the factors that have fostered support for Eurosceptic partiesat the national arena is actually the introduction of direct EP elections. Theseelections encourage a vote for small parties, which are more likely than majorparties to hold anti-EU stances.

Perhaps more importantly, this study has several implications for the evolution of national party competition over the last few decades. First, even indirectly, this study provides evidence in favor of Panebianco's (1988) view thatelectoral arenas operate as communicating vessels. Given that the same political actors are very often competing at different tiers, results in one election might generate spillover effects with potentially significant longstanding implications. And if the second-order election thesis had already pointed to such effects from national to supranational elections, the results from this study shed light on a reverse link from supranational to national arenas. In thisrespect, it might be worth exploring and further testing the argument made here using subnational elections or referenda. Importantly, these effects are not necessarily short term. Rather, given the importance of early voting experiences, they might have long-run consequences for people's voting profiles.

The last point brings us to the second contribution of this study, which relates to the pervasive effects of early political socialization. Elections, as funnels of political stimuli, denote the importance of early political experiences in the formation of distinct voting patterns over the life trajectory. Young adultsare more susceptible to events, contextual influences, and other political signalsthan their older counterparts (Ghitza \& Gelman, 2013). Here, we find that such effects leave a long-standing imprint on individuals' profiles. Moreover, they do so even if the initial stimulus is allegedly weak, as any second-order electionis expected to be (e.g., Meredith, 2009). Furthermore, even if the evidence isinconclusive, there are signals that voters do not simply develop identities as tothe exact party of support but with regard to a more encompassing group of parties that relates to their size. Previous evidence on coarse party categorizations is only scarce and primarily focused on ideological labels Bølstad and Dinas (2016). Here, we extend this line of research to consider the importance of size and find preliminary evidence of small-party voters. That said, as we do not have information on respondents' party choice in their first eligible election, these conclusions are only tentative at the moment.

Third, by looking at a largely neglected feature of European elections, this 
study provides a novel explanation of some of the most significant developments in the European political space, namely the increase of party system fragmentation and electoral volatility and the emergence of a negative incumbencyadvantage. To be sure, existing explanations based on societal change and thetransformation in the structure of political opportunities it has generated for political parties are clearly pivotal in understanding these developments. However, representative institutions - much easier to manipulate and changethan structural processes - are also contributing to this pattern. It is, thus, important to delve into these effects and appropriately investigate how they have challenged domestic partisan equilibria. Doing so might qualify the conventionalwisdom about the role of structural processes in party system fragmentation. Forinstance, one of the key explanations for the partisan dealignment in Europe is Dalton's cognitive mobilization theory, which posits that the increase in education levels of population generates more "sophisticated apartisans"; that is, newcohorts who are interested in politics but are critical toward traditional forms of political engagement, including supporting mainstream political parties (Dalton, 1984). At least in part, the introduction of EP elections could operate in a similar fashion, namely by mobilizing young voters against established parties. As these elections are affecting only more recent cohorts, they could also account forsome of the effects attributed to cognitive mobilization theory.

Even though our investigation has highlighted the importance of EP elections for performance of small parties in national elections, several questionsstill need to be addressed to better understand the working of this relationship. More specifically, future research should test the possible application of ourarguments to other second-order elections such as local and regional elections. For example, many EU countries are divided into subnational entities that elect their own Parliaments. These regional tiers of government increasinglyadminister greater portions of public budgets and decide over wider policy areas. If our arguments were valid, we would also expect that voting patternsin subnational elections spill over onto national elections, especially among voters not yet socialized into patterns of habitual voting. Moreover, it wouldbe important to assess the explanatory power of our proposed theory relativeto other classic determinants of the fragmentation of national party systems. Especially electoral systems change only very occasionally, and social heterogeneity evolves very slowly. So it is quite possible that our reasoning providesa better account of the increasing number of parties registered in European countries in recent times than previous studies. Finally, if our reasoning is true, the incentives of large parties in government to call early elections would be modified to hold them in a point in time as much close as possible from the next EP election. In either way, we hope that our article will trigger the interestnecessary to address some of these questions and improve our understandingof why European party systems are transformed over time. 


\section{Notes}

1. Parliamentary elections across all nine (at the time) European community member states were held for the first time by universal suffrage in 1979, and have taken place every 5 years since then. Special by-elections are usually organized when a country becomes a new member state in the middle of the term.

2. Although the European Parliament (EP) has gained more power over time, and even pan-European political parties fielded candidates for president of the Commission for the first time in 2014, more recent literature has generally confirmed that the second-order thesis also held in subsequent EP elections (e.g., Hobolt, 2014).

3. That said, without qualifying our theoretical predictions, looking at the motives driving an EP vote is helpful in shedding more light on the causal mechanism. In the online appendix, we delve into this question, implementing a series of empirical tests which suggest that EP eligibles do not differ from national eligible in their stances and the importance they attach to the European Union (EU). This finding implies that the reason EP elections encourage national votes for small parties is not because the EU becomes more important for them at the national level but rather due to the habit-formation implications of the secondorder nature of these elections.

4. Against this, other scholars put forward an alternative cyclical model accordingto which second-order effects increase until the midterm, and then decrease as thenext first-order election approaches (Marsh \& Franklin, 1996; Reif, 1984; Weber,2011). We remain agnostic about the exact functional form of the effect of the distance between national and EP elections on parties' vote shares in the latter. That said, the pattern shown in the next section clearly supports the monotone hypothesis. However, in the online appendix we delve into this question by implementing a series of additional analyses that test the possibility of a curvilinear relationship.

5. As explained below, comparisons only based on eligibility status, without making adjustments for the potential presence of noncompliers, allow us to detect and causally estimate intent-to-treat effects, which represent a lower bound of average treatment effects (Angrist \& Pischke, 2008).

6. Of course, we would need panel data to reconstruct the first vote. Such data do not exist for the entire EU; moreover, they are typically confined within a narrowtime frame. To allow broad coverage both across space and over time, we optedfor a conservative research strategy, which can however display informative quantities of interest (intent-to-treat effects) and can accommodate large-scale repeated cross sections, and used the European Election Studies (EES) surveys.

7. Because of the collapse of the Italian party system in the early 1990s, we excluded the respondents from this country that entered the electorate before 1994. For obvious reasons, we also excluded East Germany respondents who came of age before 1990 when they were identifiable (i.e., only for the 1994 EES survey). The mainresults presented in the article include all Germans when it is not possible to identify their region of origin because West Germany is the modal category. However,results are robust to the exclusion of all Germans who came of age before 1990 (available upon request).

8. To the best of our knowledge, respondents' birthdates are not available in any EUwide survey.

9. We can, by contrast, assume that those respondents who turn 18 in a year when a national election takes place are eligible to vote for the first time in a national 
election if the next national election takes place before the next EP election.

10. Given that we distinguish individuals on the basis of their year of birth, another potential confound apart from age is the year of their first election. When graphing the density for each group, we also find a zigzagged pattern, with the EP eligibles having a mean year of 1990.53 , whereas the national eligibles have a meanyear of 1988.16. Although small, with $n=15,118$ this difference is statistically significant ( $p$ $<.01)$. This is why all models include EP parliamentary terms as covariate to denote the different periods in which each individual has come of age. We also check for balance in item nonresponse using the missing values of the categorical covariates as a reference category. Doing so allows us to compare the models using the same number of observations in each analysis.

11. This means that we cannot directly assess the first-stage criterion because we do not have information on vote choice in the first eligible election. That said, almost all previous studies have demonstrated that small parties are favored in EP elections. Likewise, it could seem that low turnout in EP elections is also a problem for our empirical strategy. However, it is exactly the opposite: Lower turnout rates in EP elections make it even more difficult to find significant effects for our treatment because abstention means noncompliance with treatment status.

12. It might be that the differences in the length of the national election cycles between countries or other institutional factors have an impact on the probability of receiving the treatment (voting first in an EP election). To the extent that these differences could confound the outcome, we also include country-fixed effects in our estimation.

13. Average district magnitude ranges from 1 for single-member district systems (i.e., the United Kingdom and France) to 672 in Germany in 1994. With regard to the latter, we follow Shugart and Wattenberg's (2001) suggestion for mixedmember proportional systems and take the district magnitude of the list tier as average district magnitude.

14. All results remain substantively identical when using dichotomous dependent variable models (available upon request).

15. Sources: Nohlen and Stöver (2010) and Comparative Parliamentary Democracy Archive (www.erdda.se).

16. Our analysis examines the difference in the aggregate vote share of parties between the EP and the previous national election, conditional on the electoral cycle. We find a monotone decreasing pattern for large parties and a monotone increasing pattern for small parties. All figures suggest that a linear function approximates very well the relationship between Cycle and change in parties' vote share between national and EP elections.

17. The complete results of this exercise are presented in the online appendix.

18. In the online appendix, we allow for a more flexible estimation, adding a higher polynomial and thus remaining agnostic about the monotonicity of the relationship between Cycle and parties' vote shares. Figure A1 confirms the monotonically positive moderating effect of Cycle on the relationship between EPEligible and futurevote choice. Full details of these estimates are also provided in the online appendix.

19. Figure $\mathrm{A} 2$ in the online appendix repeats this exercise, including observations with $D M$ up to 15 , hence avoiding problems of extreme interpolations. The results are substantively identical. 


\section{References}

Angrist, J. D., \& Pischke, J.-S. (2008). Mostly harmless econometrics. Princeton, NJ: Princeton University Press.

Beasley, R. K., \& Joslyn, M. R. (2001). Cognitive dissonance and post-decision attitude change in six presidential elections. Political Psychology, 22, 521-540.

Best, R. E. (2010). Increasing irrationality? The equilibrium relationship between electoral and legislative party system size, 1950-2005. Electoral Studies, 29, 105116.

Bølstad, J., \& Dinas, E. (2016). A categorization theory of spatial voting: How the center divides the political space. British Journal of Political Science, 47, 829850. doi:10.1017/S0007123415000393

Bølstad, J., Dinas, E., \& Riera, P. (2013). Tactical voting and party preferences: A testof cognitive dissonance theory. Political Behavior, 35, 429-452.

Brehm, J. W. (1956). Postdecision changes in the desirability of alternatives. Journalof Abnormal and Social Psychology, 52, 384-389.

Carrubba, C., \& Timpone, R. J. (2005). Explaining vote switching across first-and second-order elections: Evidence from Europe. Comparative Political Studies, 38, 260-281.

Clark, N., \& Rohrschneider, R. (2009). Second-order elections versus first-order thinking: How voters perceive the representation process in a multi-layered system of governance. European Integration, 31, 645-664.

Converse, P. E. (1969). Of time and partisan stability. Comparative Political Studies,2, 139-171.

Cox, G. W. (1997). Making votes count: Strategic coordination in the world's electoral systems. Cambridge, UK: Cambridge University Press.

Crewe, I., \& Denver, T. D. (1985). Electoral change in Western democracies: Patterns and sources of electoral volatility. London, UK: Croom Helm.

Curtice, J. (1989). The 1989 European election: Protest or green tide? Electoral Studies, $8,217-230$.

Dalton, R. J. (1984). Cognitive mobilization and partisan dealignment in advanced industrial democracies. The Journal of Politics, 46, 264-284.

Dalton, R. J. (2002). Citizen politics: Public opinion and political parties in advanced industrial democracies (3rd ed.). Washington, DC: CQ Press.

Dalton, R. J., Farrell, D., \& McAllister, I. (2011). Political parties and democratic linkage. Oxford, UK: Oxford University Press.

Dalton, R. J., \& Wattenberg, M. P. (2002). Parties without partisans. Oxford, UK: Oxford University Press.

Delli Carpini, M. (1989). Age and history: Generations and sociopolitical change.In R. Sigel (Ed.), Political learning in adulthood (pp. 11-55). Chicago, IL: The University of Chicago Press.

de Vries, C. E. (2007). Sleeping giant: Fact or fairytale? How European integration affects national elections. European Union Politics, 8, 363-385.

Dinas, E. (2013). Opening "openness to change": Political events and the increased sensitivity of young adults. Political Research Quarterly, 66, 868-882.

Dinas, E. (2014). Does choice bring loyalty? Electoral participation and the development of party identification. American Journal of Political Science, 58, 449-465.

Duverger, M. (1964). Political parties: Their organization and activity in the modern state. London, UK: Methuen. (Original work published 1954) 
Erikson, R. S. (1988). The puzzle of midterm loss. The Journal of Politics, 50, 10111029.

Erikson, R. S., \& Filippov, M. G. (2001). Electoral balancing in federal and subnational elections: The case of Canada. Constitutional Political Economy, 12, 313331.

Evans, G., \& Tilley, J. (2012). How parties shape class politics: Explaining the decline of the class basis of party support. British Journal of Political Science, 42, 137 161.

Ezrow, L., de Vries, C., Steenbergen, M., \& Edwards, E. (2011). Mean voter representation and partisan constituency representation: Do parties respond to the mean voter position or to their supporters? Party Politics, 17, 275-301.

Festinger, L. (1957). A theory of cognitive dissonance. Evanston, IL: Row, Peterson.

Festinger, L., \& Carlsmith, J. M. (1959). Cognitive consequences of forced compliance. Journal of Abnormal and Social Psychology, 58, 203-210.

Franklin, M. N. (2004). Voter turnout and the dynamics of electoral competition in established democracies since 1945. New York, NY: Cambridge University Press.

Franklin, M. N., \& Hobolt, S. B. (2011). The legacy of lethargy: How elections to the European Parliament depress turnout. Electoral Studies, 30, 67-76.

Franklin, M. N., Mackie, T. T., \& Valen, H. (1992). Electoral change: Responses to evolving social and attitudinal structures in Western nations. Cambridge, UK: Cambridge University Press.

Gallagher, M. (1991). Proportionality, disproportionality and electoral systems. Electoral Studies, 10, 33-51.

Gerber, A. S., Green, D. P., \& Shachar, R. (2003). Voting may be habit-forming: Evidence from a randomized field experiment. American Journal of Political Science, 47, 540-550.

Ghitza, Y., \& Gelman, A. (2013). Deep interactions with MRP: Election turnout and voting patterns among small electoral subgroups. American Journal of Political Science, 57, 762-776.

Green, D. P., \& Shachar, R. (2000). Habit formation and political behavior: Evidence of consuetude in voter turnout. British Journal of Political Science, 30, 561-573.

Hix, S., \& Marsh, M. (2007). Punishment or protest? Understanding European Parliament elections. The Journal of Politics, 69, 495-510.

Hix, S., \& Marsh, M. (2011). Second-order effects plus pan-European political swings: An analysis of European Parliament Elections across time. Electoral Studies, 30, 4-15.

Hobolt, S. B. (2014). A vote for the president? The role of Spitzenkandidaten in the 2014 European Parliament elections. Journal of European Public Policy, 21, 1528-1540.

Hobolt, S. B., Spoon, J.-J., \& Tilley, J. (2009). A vote against Europe? Explaining defection at the 1999 and 2004 European Parliament elections. British Journal of Political Science, 39, 93-115.

Hobolt, S. B., \& Wittrock, J. (2011). The second-order election model revisited: An experimental test of vote choices in European Parliament Elections. Electoral Studies, 30, 29-40.

Knutsen, O. (1998). The strength of the partisan component of left-right identity. A comparative longitudinal study of left-right party polarization in eight West European countries. Party Politics, 4, 5-31.

Kriesi, H., Grande, E., Lachat, R., Dolezal, M., Bornschier, S., \& Frey, T. (2008). West European politics in the age of globalization. Cambridge, UK: Cambridge 
University Press.

Lipset, S. M., \& Rokkan, S. (1967). Party systems and voter alignments: Crossnational perspectives. Toronto, Ontario, Canada: The Free Press.

Lupu, N. (2013). Party brands and partisanship: Theory with evidence from a survey experiment in Argentina. American Journal of Political Science, 57, 49-64.

Mair, P. (2002). In the aggregate: Mass electoral behavior in Western Europe, 19502000. In H. Keman (Ed.), Comparative democratic politics (pp. 122-140). London, UK: Sage.

Mair, P. (2005). Democracy beyond parties (Working Paper No. 05'06). Irvine: Center for the Study of Democracy, University of California.

Markus, G. B., \& Converse, P. E. (1979). A dynamic simultaneous equation model of electoral choice. American Political Science Review, 73, 1055-1070.

Marsh, M. (1998). Testing the second-order election model after four European elections. British Journal of Political Science, 28, 591-607.

Marsh, M., \& Franklin, M. (1996). The foundations: Unanswered questions from the study of European elections, 1979-1994. In C. van der Eijk \& M. N. Franklin (Eds.), Choosing Europe? (pp. 11-32). Ann Arbor, MI: University of Michigan Press.

McPhee, W., \& Ferguson, J. (1962). Political immunization. In W. McPhee \& W. A. Glaser (Eds.), Public opinion and congressional elections (pp. 155-179). New York, NY: The Free Press.

Meredith, M. (2009). Persistence in political participation. Quarterly Journal of Political Science, 4, 187-209.

Mullainathan, S., Schwartzstein, J., \& Shleifer, A. (2008). Coarse thinking and persuasion. The Quarterly Journal of Economics, 123, 577-619.

Mullainathan, S., \& Washington, E. (2009). Sticking with your vote: Cognitive dissonance and political attitudes. Applied Economics, 1, 86-111.

Narud, H. M., \& Valen, H. (2008). Coalition membership and electoral performance in Western Europe. In K. Strøm, W. C. Müller, \& T. Bergmann (Eds.), Cabinets and coalition bargaining: The democratic life cycle in Western Europe (pp. 369402). Oxford, UK: Oxford University Press.

Nohlen, D., \& Stöver, P. (2010). Elections in Europe: A data handbook. BadenBaden, Germany: Nomos Verlag-Ges.

Oppenhuis, E., van der Eijk, C., \& Franklin, M. (1996). The party context: Outcomes. In C. van der Eijk \& M. N. Franklin (Eds.), Choosing Europe? (pp. 287-305). Ann Arbor, MI: University of Michigan Press.

Panebianco, A. (1988). Political parties: Organization and power (Vol. 6). New York, NY: Cambridge University Press.

Plutzer, E. (2002). Becoming a habitual voter: Inertia, resources, and growth in young adulthood. American Political Science Review, 96, 41-56.

Reif, K. (1984). National electoral cycles and European Elections 1979 and 1984. Electoral Studies, 3, 244-255.

Reif, K., \& Schmitt, H. (1980). Nine second-order national elections-A conceptual framework for the analysis of European Election results. European Journal of Political Research, 8, 3-44.

Rohrschneider, R., \& Whitefield, S. (2012). The strain of representation. Oxford, UK: Oxford University Press.

Rose, R., \& Mackie, T. (1983). Incumbency in government: Asset or liability. In H. Daalder \& P. Mair (Eds.), Western European party systems: Continuity and 
change (pp. 115-138). London, UK: Sage.

Schuman, H., \& Corning, A. D. (2012). Generational memory and the critical period: Evidence for national and world events. Public Opinion Quarterly, 76, 1-31.

Sears, D. O. (1983). The persistence of early political predispositions: The roles of attitude object and life stage. In L. Wheeler \& P. Shaver (Eds.), Review of personality and social psychology (Vol. 4, pp. 79-116). Beverly Hills, CA: Sage.

Shachar, R. (2003). Party loyalty as habit formation. Journal of Applied Econometrics, $18,251-269$.

Shugart, M. S., \& Wattenberg, M. P. (2001). Mixed-member electoral systems: The best of both worlds? New York, NY: Oxford University Press.

Stoker, L., \& Jennings, K. M. (2008). Of time and the development of partisan polarization. American Journal of Political Science, 52, 619-635.

Strøm, K. (1990). Minority government and majority rule. Cambridge, UK: Cambridge University Press.

Turner, J. C. (1982). Towards a cognitive redefinition of the group. In H. Tajfel (Ed.), Social identity and intergroup relations (pp. 15-40). Cambridge, UK: Cambridge University Press.

van der Brug, W., \& van der Eijk, C. (2007). European elections \& domestic politics: Lessons from the past and scenarios for the future. Notre Dame, IN: University of Notre Dame Press.

van der Eijk, C., \& Franklin, M. N. (1996). Choosing Europe? The European electorate and national politics in the face of union. Ann Arbor, MI: University of Michigan Press.

van Egmond, M., van der Brug, W., Hobolt, S., Franklin, M., \& Sapir, E. V. (2011). European Parliament election study 2009, voter study (GESIS Data Archive, Cologne, ZA5055 Data File Version 1.1.0). doi:10.4232/1.11760

Weber, T. (2011). Exit, voice, and cyclicality: A micrologic of midterm effects in European Parliament elections. American Journal of Political Science, 55, 907-922. 


\section{Figures}

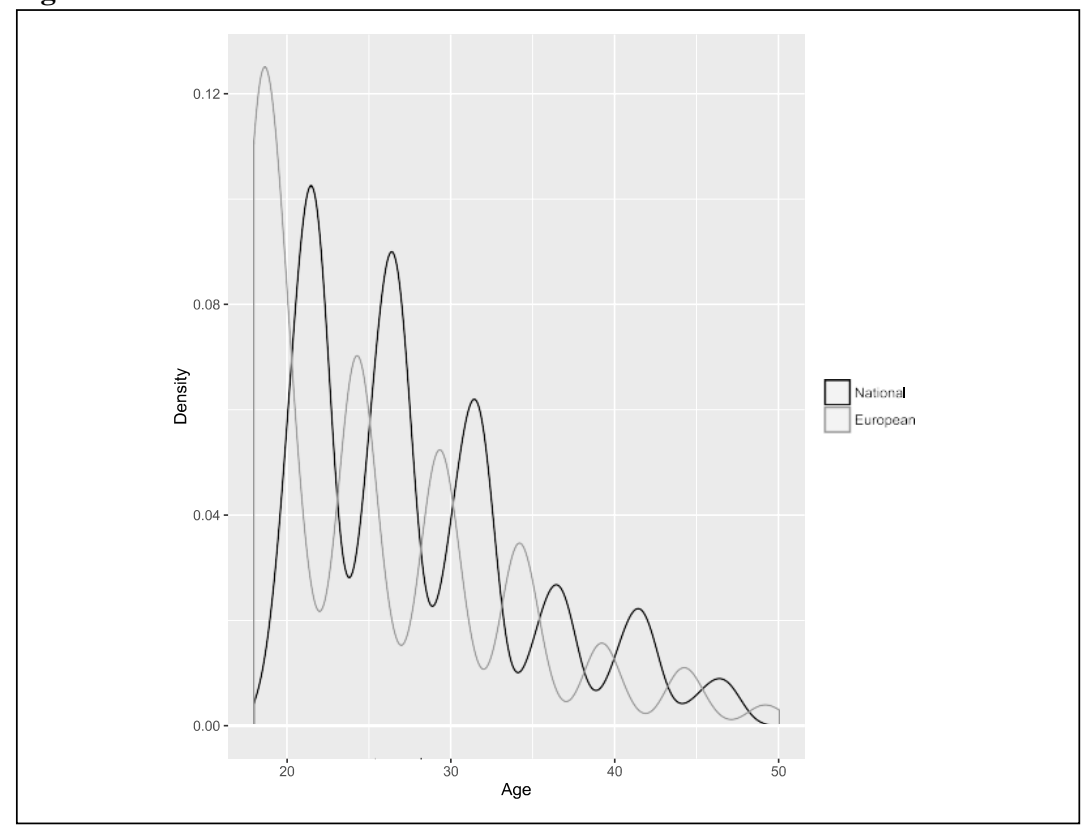

Figure 1. Density plot of age, for EP eligibles and national eligibles.

A Gaussian kernel has been used for the densities. EP = European Parliament. 


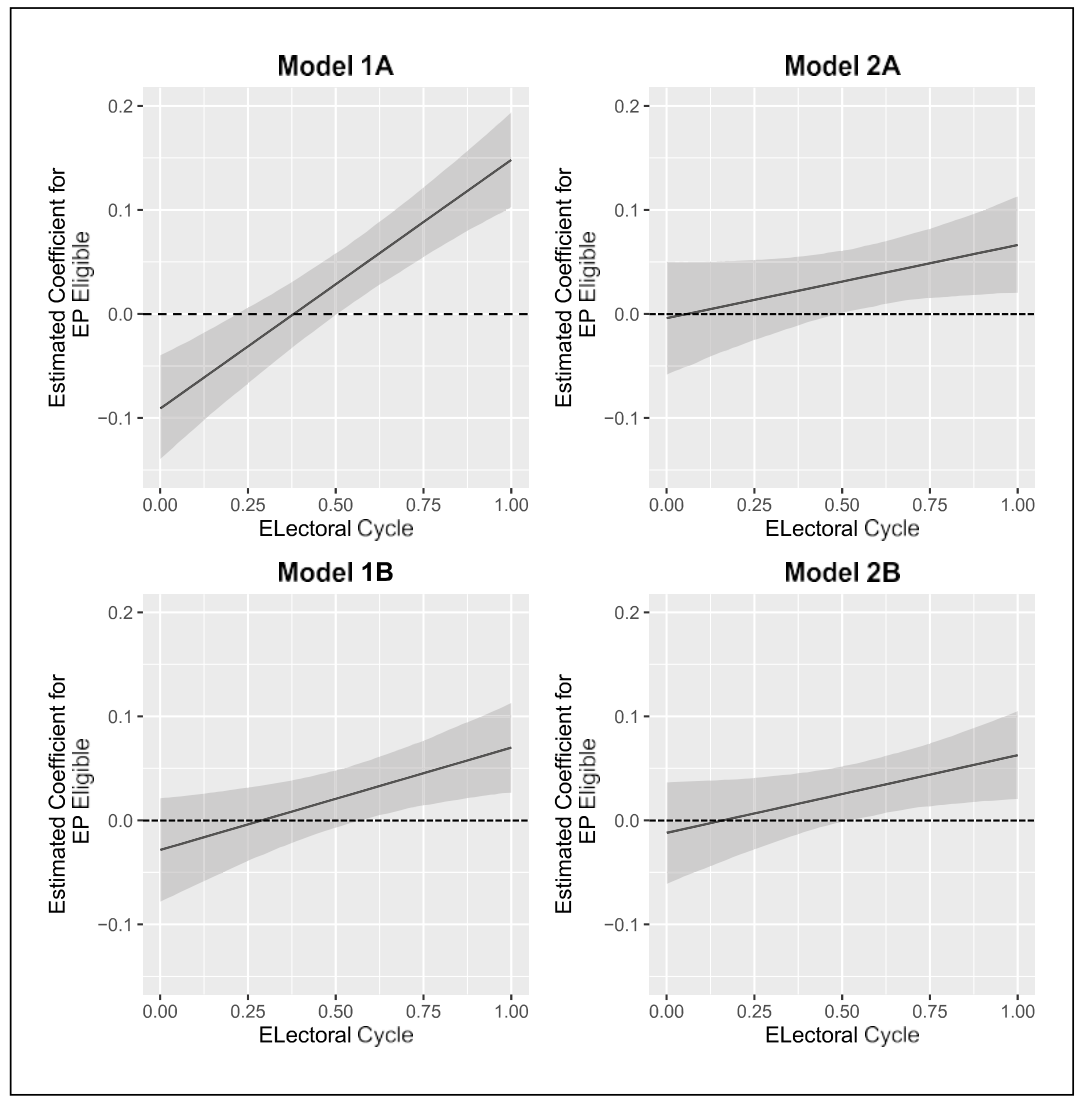

Figure 2. The marginal effect of EP eligibility on voting for a small party in the nextnational election conditional on national electoral cycle.

The solid line denotes the marginal effect of EP eligibility on small-party vote, conditional on the distance between the socializing EP election and the previous national one. The shaded areas capture the $95 \%$ confidence intervals. The estimates are derived from a model including Cycle interacted with EP eligibility. Model 1a only uses the current national election and treats as small all parties apart from the first two. Model $1 \mathrm{~b}$ measures small parties in the same waybut in both the national and the first eligible elections. Models $2 \mathrm{a}$ and $2 \mathrm{~b}$ are similar apartfrom measuring small parties as those with vote share below $10 \%$. All key estimates remain practically identical when the control variables of the previous analyses are included. EP = European Parliament. 


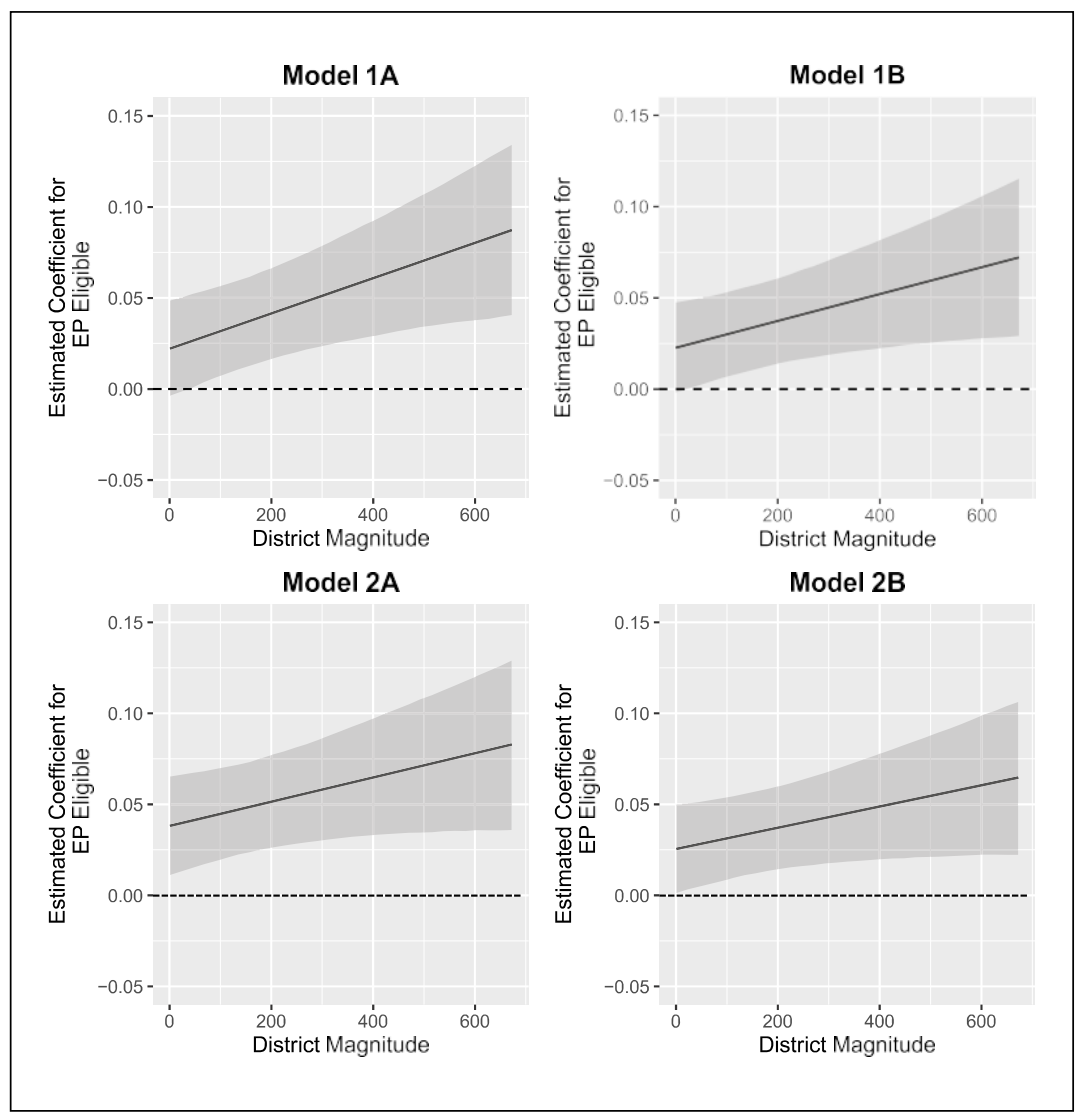

Figure 3. The marginal effect of EP eligibility on voting for a small party in the nextnational election conditional on national average district magnitude.

The solid line denotes the marginal effect of EP eligibility on small-party vote, conditionalon the national average DM. The shaded areas capture the 95\% confidence intervals. The estimates are derived from a model including $D M$ interacted with EP eligibility. Model 1aonly uses the current national election and treats as small all parties apart from the first two. Model $1 \mathrm{~b}$ measures small parties in the same way but in both the national and the first eligible elections. Models $2 \mathrm{a}$ and $2 \mathrm{~b}$ are similar apart from measuring small parties as those with vote share below $10 \%$. All key estimates remain practically identical when the control variables of the previous analyses are included. EP = European Parliament; $\mathrm{DM}=$ district magnitude. 